\title{
Thymoquinone exerts potent growth-suppressive activity on leukemia through DNA hypermethylation reversal in leukemia cells
}

\author{
Jiuxia Pang ${ }^{1}$, Na Shen ${ }^{1}$, Fei Yan ${ }^{1}$, Na Zhao ${ }^{1}$, Liping Dou ${ }^{1,2}$, Lai-Chu Wu ${ }^{3}$, Christopher \\ L. Seiler ${ }^{4}$, Li $\mathbf{Y u}^{2}$, Ke Yang ${ }^{5}$, Veronika Bachanova ${ }^{6}$, Eric Weaver, Natalia Y. \\ Tretyakova ${ }^{4}$, Shujun Liu ${ }^{1}$ \\ ${ }^{1}$ The Hormel Institute, University of Minnesota, Austin, MN 55912, USA \\ ${ }^{2}$ Department of Hematology, Chinese PLA General Hospital, Medical School of Chinese PLA, Beijing 100853, China \\ ${ }^{3}$ Department of Biological Chemistry and Pharmacology, The Ohio State University, Columbus, OH 43021, USA \\ ${ }^{4}$ Department of Medicinal Chemistry, University of Minnesota, Minneapolis, MN 55455, USA \\ ${ }^{5}$ Chongqing Engineering Research Center of Stem Cell Therapy, The Children's Hospital of Chongqing Medical University, \\ Chongqing 400014, China \\ ${ }^{6}$ Division of Hematology, Oncology and Transplantation, Minneapolis, MN 55455, USA \\ ${ }^{7}$ Prairie Pharms LLC, Nora Springs, IA 50458, USA \\ Correspondence to: Shujun Liu, email: sliu@umn.edu
}

Keywords: DNA methylation, leukemia, thymoquinone, DNA methyltransferase, bioactive compounds

Received: February 10, $2017 \quad$ Accepted: March 14, 2017 Published: March 21, 2017

Copyright: Pang et al. This is an open-access article distributed under the terms of the Creative Commons Attribution License (CC-BY), which permits unrestricted use, distribution, and reproduction in any medium, provided the original author and source are credited.

\section{ABSTRACT}

Thymoquinone (TQ), a bioactive constituent of the volatile oil of Monarda fistulosa and Nigella sativa, possesses cancer-specific growth inhibitory effects, but the underlying molecular mechanisms remain largely elusive. We propose that TQ curbs cancer cell growth through dysfunction of DNA methyltransferase 1 (DNMT1). Molecular docking analysis revealed that TQ might interact with the catalytic pocket of DNMT1 and compete with co-factor SAM/SAH for DNMT1 inhibition. In vitro inhibitory assays showed that TQ decreases DNMT1 methylation activity in a dose-dependent manner with an apparent IC50 of $30 \mathrm{nM}$. Further, exposure of leukemia cell lines and patient primary cells to TQ resulted in DNMT1 downregulation, mechanistically, through dissociation of Sp1/NFkB complex from DNMT1 promoter. This led to a reduction of DNA methylation, a decrease of colony formation and an increase of cell apoptosis via the activation of caspases. In addition, we developed and validated a sensitive and specific LC-MS/MS method and successfully detected a dynamic change of TQ in mouse plasma after administration of TQ through the tail vein, and determined a tolerable dose of TQ to be $15 \mathrm{mg} / \mathrm{kg}$ in mouse. TQ administration into leukemiabearing mice induced leukemia regression, as indicated by the reversed splenomegaly and the inhibited leukemia cell growth in lungs and livers. Our study for the first time demonstrates that DNMT1-dependent DNA methylation mediates the anticancer actions of TQ, opening a window to develop TQ as a novel DNA hypomethylating agent for leukemia therapy.

\section{INTRODUCTION}

Acute myeloid leukemia (AML) is a highly aggressive hematologic malignancy characterized by an uncontrollable proliferation of immature myeloid blasts. While intensive chemotherapy, usually consisting of an anthracycline and cytarabine, induces remission in about $50 \%$ of older patients, most of these patients still succumb to their disease. New approaches improving outcome in AML are highly needed. Overexpression of DNA methyltransferases (DNMTs) is frequent and changes in DNA methylation are a constant feature of AML [1-3]. 
Consequently, abnormal DNA methylation has been an attractive target for therapy in AML. Inhibitors for DNMT1, such as azacitidine and decitabine, have entered into clinical trials for AML patients [4-6]. An accepted mechanism for the anti-tumor activity of these agents is their incorporation into newly synthesized DNA strands followed by covalent binding, sequestration and depletion of the DNMT1 [6-8]. Although positive clinical outcomes have been achieved in certain patients, the prognosis remains poor due to the relapse and/or non-responsiveness. Mechanistically, such high failure rate of therapy could result from the drawbacks of decitabine, including cell cycle-dependent activity, low efficiency of DNA incorporation [9] and lack of obvious inhibitory effects on DNMT3a and DNMT3b [10]. Thus, the development of novel DNA hypomethylating compounds with different action mechanisms may broaden the therapeutic toolbox targeting epigenetic abnormality in AML.

Natural products from plants are becoming more and more interesting, because they are relatively nontoxic, inexpensive and available in an ingestive form [11] with significant anticancer effects. Preclinical and clinical studies demonstrated that the anticancer properties of bioactive components (i.e., pathenolide, folate, retinoids etc.) may be attributed to its influence on epigenetic processes through binding to DNMT1 enzymatic center or/and disrupting DNMT transcription [12]. TQ is one of the most bioactive ingredients of Nigella Sativa seeds, which is regarded in the Middle East as part of an overall holistic approach to health and is thus incorporated into diets and everyday lifestyles. TQ is also found in high concentration in the prairie plant Monarda fistulosa, known as wild bergamot. It is reported that TQ exerts significant anti-neoplastic activity against human cancers [13], anti-oxidant effects and anti-inflammation in animal models and cell culture systems $[14,15]$, chemopreventive effects, most importantly, the specific growth inhibitory effects on cancer cells, not normal cells [16, 17], and antimultidrug-resistant variants of human malignant cell [13]. However, how TQ manifests these activities is not fully understood, although it has been shown to downregulate the expression of Bcl-xL [18], COX-2 [19], iNOS [20], 5-LOX [21], TNF [22] and cyclin D1 [16], all known to be regulated by NFkB activity that can be blocked by TQ [23]. Given the regulatory role of NFkB in DNMT1 expression $[1,2,24]$, these investigations support the notion that TQ may influence epigenetic events in cancer cells, which has not been studied.

In the current report, we investigated the molecular mechanisms of TQ anti-leukemia actions. We demonstrate that TQ binds to the DNMT1 catalytic site leading to inhibition of DNMT1 enzymatic activity, and that TQ mediates DNMT1 downregulation, at least partially, through disruption of $\mathrm{Sp} 1 / \mathrm{miR}-29 \mathrm{~b}$ loop resulting in a reduction of DNA methylation. Consequently, TQ promoted cell growth arrest, apoptosis in vitro and ex vivo and induced leukemia regression in mice. These findings support TQ as an additional DNA methylation modulator that mechanistically differs from conventional hypomethylating agents.

\section{RESULTS}

\section{Molecular modeling of TQ binding to DNMT1 catalytic site}

It is well known that the dietary phytochemicals (e.g., curcumin, lycopene, genistein) reverse abnormal DNA methylation landscape in various types of cancer [25, 26], but it is unknown whether TQ, another phytochemical compound, possesses inhibitory activity on DNMT1dependent DNA methylation. To address this, a homology model of human DNMT1 catalytic domain was initially built with the crystal structure of bacterial modification methylase (Hhal) catalytic domain (PDB ID 4MHT) as the modeling template (Figure 1A). AutoDock version 4.051 was used for the docking simulation. Figure 1B showed simulated bindings of TQ and cofactor SAH onto the catalytic site of DNMT1 homology model. The DNMT1 catalytic site was a deep pocket buttressed by a typical pseudo-Rossmann fold in the bottom and walled by helices and loops. The pocket was largely hydrophobic with polar residues in the binding sub-pockets on the methionine end of the cofactor and at the side of pyrimidine aromatic ring of the substrate. TQ binding competes mainly with the adenosine side of cofactor. The phenyl ring was sandwiched between Trp1136 and Phe1111 via strong aromatic interaction, and one of the carbonyl groups was H-bonded to Glu1168 main-chain amide. These results support the potential of TQ to inhibit DNMT1 catalytic function.

\section{TQ inhibits DNMT1 activity in vitro}

As TQ was predicted to bind to the DNMT1 catalytic site, we reasoned that TQ would ablate DNMT1 activity. To test this, we performed in vitro inhibitory assay [25] of TQ on the enzymatic activity of M. SssI, an analog of DNMT1 with robust methylation activity. Its catalytic domain was structurally similar to DNMT1. In brief, we used a $38 \mathrm{bp}$ double stranded (ds)-oligonucleotide containing the sequence CCGG, which was labeled with 3'-biotin in one strand and 3'-digoxigenin-NHS ester in its complementary strand. When CCGG was methylated $\left(\mathrm{CC}^{\mathrm{m}} \mathrm{GG}\right)$, HpalI was unable to cleave it resulting in the generation of fluorescence signal that was positively correlated with M. SssI enzymatic activity. As shown in Figure 1C, exposure to various concentrations $(1,10,30$ and $300 \mathrm{nM}, 1,3,10,30$ and $100 \mu \mathrm{M})$ of TQ led to a dose-dependent decrease in fluorescent intensity, reflecting inhibition of the M. SssI methylation activity. Curcumin, another DNA methylation modulator [25], was used as a 
positive control. The apparent $\mathrm{IC}_{50}$ of TQ with respect to M. SssI inhibition was $30 \mathrm{nM}$. Although the exact binding mode of TQ to DNMT1 catalytic center needs further exploration, these data support the inhibitory effect of TQ on DNMT1 partially through protein binding.

\section{TQ abrogates DNMT1 expression through Sp1/ $m i R-29 b$ negative feedback loop}

As DNMT1 gene abundance is an important regulator of DNA methylation [1, 2, 8, 24], and given that TQ impairs NFkB signaling, a DNMT1 gene transactivator $[1,2,24]$, we hypothesized that TQ treatment inhibits DNMT1 expression coupled with DNA hypomethylation. To test this, we treated leukemia cells, including ML-1, Kasumi-1 and MV4-11, with indicated doses of TQ and initially employed Western blot to assess DNMT1 changes. As expected, the expression of DNMT1, DNMT3a and Sp1, but not HSP90, was significantly decreased in these cell lines (Figure 2A), which was further verified in THP1 and K562 cells upon exposure to TQ (not shown). As $m i R-29 b$ directly binds to the 3'-UTR of Sp1, DNMT3a and DNMT3b $[27,28]$ thereby disrupting their expression, we measured $m i R-29 b$ levels and observed an upregulation of $m i R-29 b$ in the presence vs. absence of TQ (Figure 2B).

To dissect the molecular mechanisms underlying TQmediated DNMT1 downregulation, we initially employed electrophoretic mobility shift assays (EMSA) [24, 27-29] and used the probes spanning the regions containing Sp1/NFkB binding elements in DNMT1 promoter. As shown in Figure $2 \mathrm{C}$, when the nuclear extracts (NE) prepared from MV4-11 and THP-1 cells were incubated with ${ }^{32} \mathrm{P}$-labled probes, Sp1/NFkB-DNA complex was detected in control group, but was significantly reduced in TQ-treated cells. This result supports the notion that $\mathrm{Sp} 1 / \mathrm{NFkB}$ complex in DNMT1 promoter was disrupted by TQ treatment, which might result from TQ-mediated Sp1 downregulation (see Figure 2A). To further verify the $\mathrm{Sp} 1 / \mathrm{NFkB}$ complex in DNMT1 promoter, we performed Chromatin Immunoprecipitation (ChIP) assays [3, 27, 30]. Briefly, the treated cells were fixed in formaldehyde, sonicated, immunoprecipitated by antibodies against $\mathrm{Sp} 1$ or the p65 subunit of NFkB. The precipitated DNA was qPCR-amplified using primers covering the Sp1/NFkB

A

Total 478 amino acids of catalytic domain
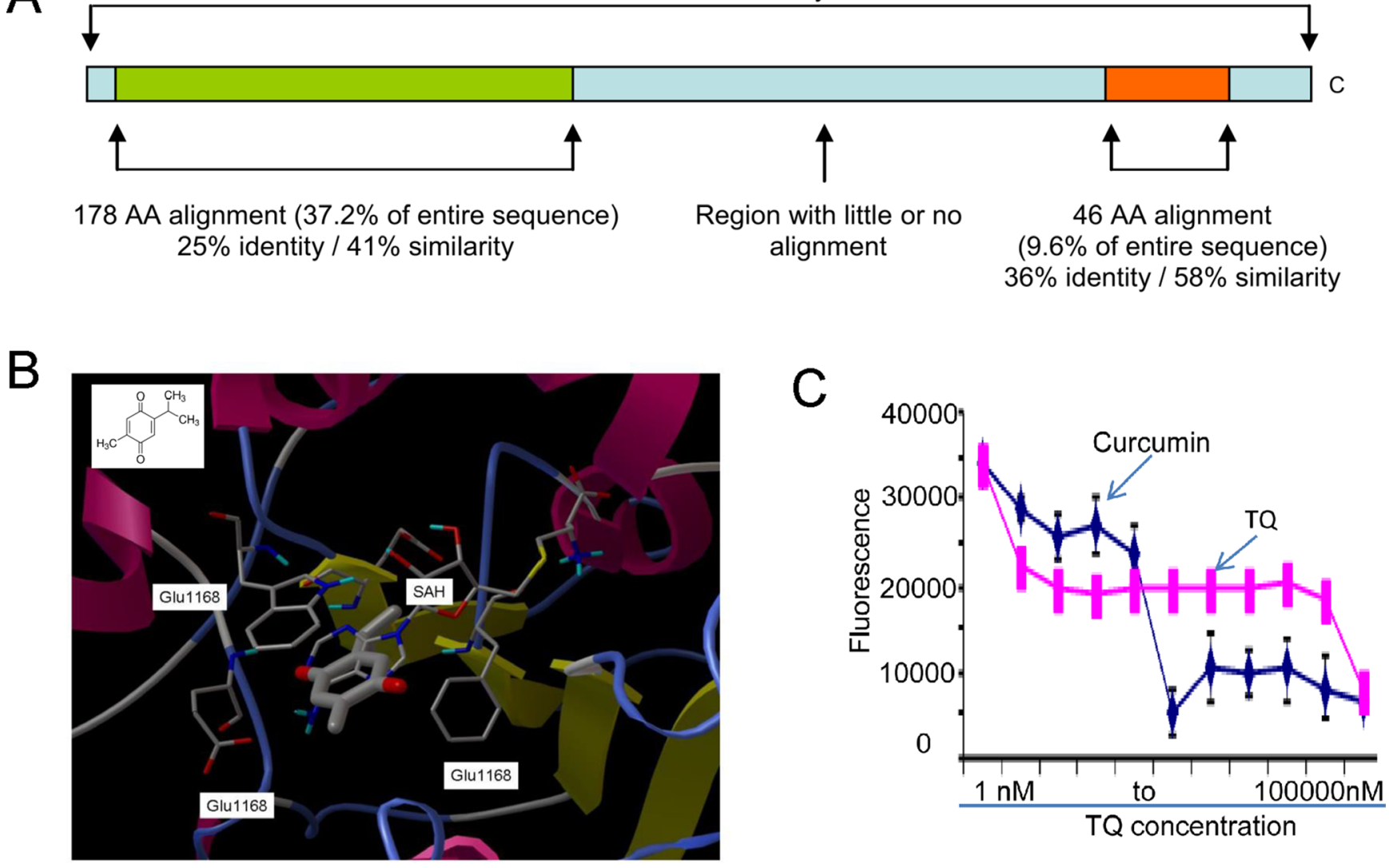

Figure 1: TQ binds to DNMT1 catalytic pocket. (A) Schematic diagram of the alignment of bacterial modification methylase (Hhal) catalytic domain (PDB ID: 4MHT) against the 478 amino acids (AA 1139-1616) of DNMT1. (B) TQ (thick ball-and-stick) binding to DNMT1 catalytic site (ribbon representation). Important binding site residues are shown as thin ball-and-stick and labeled, cofactor SAH shown as thin ball-and-stick and TQ structure shown at upper left corner. TQ largely competes with cofactor SAM/SAH for DNMT1 inhibition. (C) In vitro inhibitory assay of TQ on the enzymatic activity of M. SssI. Data are mean $\pm \mathrm{SD} ; * p<0.01$. 
binding sites, and the results were normalized by the respective input DNA. TQ treatment abrogated the binding of Sp1/NFkB to DNMT1 promoter in a dose-dependent manner, suggesting that TQ impairs DNMT1 expression through Sp1 and NFkB dysfunction (Figure 2D). Because our studies and others demonstrated that $\mathrm{Sp} 1 / \mathrm{NFkB}$ is also involved in the regulation of tyrosine kinase signaling [27, 31], as a proof of concept, we examined the changes of KIT and FLT3, the key regulators of leukemia pathogenesis. We found that exposure of Kasumi-1 and MV4-11 cells to TQ led to downregulation of KIT, FLT3, STAT5 and AKT followed by dephosphorylation of STAT5 and AKT (Figure 2E), indicating tyrosine kinase signaling as an additional molecular mechanism behind TQ-induced leukemia growth arrest, which merits a systematic characterization.

\section{TQ induces global DNA hypomethylation, blocks colony formation and promotes cell apoptosis in vitro}

Considering that DNMT1 gene abundance positively modulates DNA methylation levels [1, 2, 24], we next sought to address whether DNA methylation is decreased in the presence of TQ. In fact, the dotblot assays using anti-5mC revealed a significant reduction of DNA methylation in MV4-11 cells treated with TQ for 48 hours (Figure 3A). Because our previous studies suggested that DNMT1 upregulation [1] and DNA hypermethylation $[1,3,8,28]$ are significantly and positively associated with more aggressive leukemia growth and worse prognosis, we examined the growth status of TQ-treated cells. The results from CCK-8 assays disclosed a significant inhibition of cell proliferation (Figure $3 \mathrm{~B}$ ), and the colony assays identified a dose-dependent decrease of colony number (Figure 3C), when exposed to TQ. Further, flow cytometry assays found an enhanced cell apoptosis (Figure 3D), which possibly occurred via caspase activation, because Western blot showed that the active forms of caspase- 3 and caspase- 8 were significantly increased in the presence vs. absence of TQ (Figure 3E).

\section{TQ suppresses DNMT1-dependent DNA methylation and promotes cell apoptosis in leukemia blasts}

To explore the clinical implication of TQ as a DNA hypomethylating agent, we treated leukemia patient
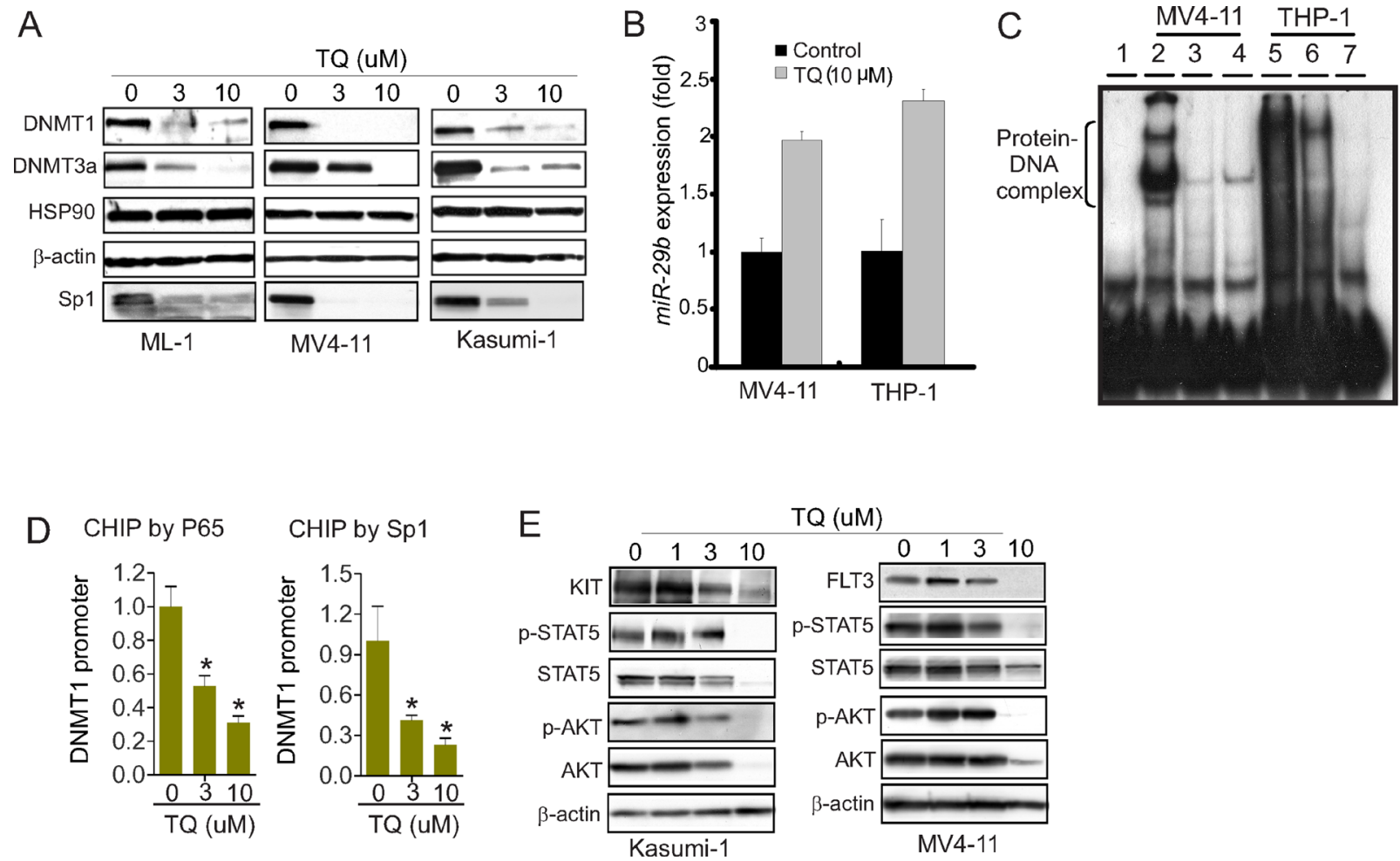

Figure 2: Treatment with TQ suppresses DNMT1 expression. (A) Western blot in ML-1, MV4-11 and Kasumi-1 cells treated with indicated amounts of TQ for 24 hours. (B) qPCR measuring $m i R-29 b$ expression in MV4-11 and THP-1 cells upon exposure to TQ for 3 hours. (C) Nuclear extract from MV4-11 and THP-1 cells treated with TQ for 24 hours was subjected to EMSA using probes derived from DNMT1 promoter covering Sp1/NFkB binding elements. Note: lane 1, free probe; lanes 2 and 5, control; lanes 3 and 6, TQ (3 $\mu$ M); lanes 3 and 7, TQ $(10 \mu \mathrm{M})$. (D) ChIP assays using anti-NFkB (p65) and anti-Sp1 in MV4-11 cells treated with indicated amounts of TQ for 24 hours. The respective input DNA was used for normalization. (E) Western blot in MV4-11 and Kasumi-1 cells treated with TQ for 24 hours. The data represent three independent experiments; Data are mean $\pm \mathrm{SD} ; * p<0.05$. 
blasts with TQ. In agreement with the results from cell lines, TQ exposure significantly decreased the expression of DNMT1, DNMT3a, Sp1, KIT and FLT3 at both RNA (Figure 4A) and protein (Figure 4B) levels. This was followed by a significant decrease of global DNA methylation (Figure 4C) and an increase of cell apoptosis (Figure 4D).

\section{Characterization of TQ pharmacokinetics}

To determine the pharmacokinetics of TQ in preclinical investigation, we have developed a LC-MS/ MS method to quantify TQ in mouse plasma. As TQ has limited aqueous solubility for the in vivo study, we initially designed an appropriate formulation to dissolve TQ. When TQ was dissolved in ethanol/PEG400/saline $(18 / 42 / 40 \%)$, a clear solution of TQ in a concentration of $7.5-13 \mathrm{mg} / \mathrm{ml}$ was achieved, which was suitable for administration of $30-50 \mathrm{mg} / \mathrm{kg}$ dose in mice. Further, as TQ was light sensitive (not shown), we used the non- conventional method to extract TQ. Briefly, TQ was dissolved in Acetonitrile (ACN) to make stock solutions at $1 \mathrm{mg} / \mathrm{mL}$. To test the linearity of the standard curve, $10 \mathrm{uL}$ of the appropriate ranged $(2-50 \mathrm{ng} / \mathrm{mL})$ intermediated stock solutions was spiked into $100 \mathrm{uL}$ of mobile phase, which was $50 \% \mathrm{ACN}$ and $0.1 \%$ formic acid. The mixture was vortexed for 30 second and $20 \mu \mathrm{L}$ was injected into the LC-MS/MS system. An Applied Biosystems Sciex API 3000 mass spectrometer (Applied Biosystems Sciex) equipped with an electrospray ionization (ESI) source was used for mass analysis and detection. The detector was operated at unit resolution in MRM mode using the transitions from the protonated molecular ions to product ions at $\mathrm{m} / \mathrm{z}$ 164.00/134.10 for TQ. A SIL-10ADvp Shimadzu HPLC system (Shimadzu) consisting of system controller, degasser, binary pump and auto-sampler was used for solvent and sample delivery. The chromatographic separation was performed using a Beta Basic C8 column $(2.1 \mathrm{~mm} \times 50 \mathrm{~mm}, 5 \mu \mathrm{m})$ coupled with a Beta Basic C8 guard column $(2.1 \mathrm{~mm} \times 10 \mathrm{~mm}, 5 \mu \mathrm{m})$.
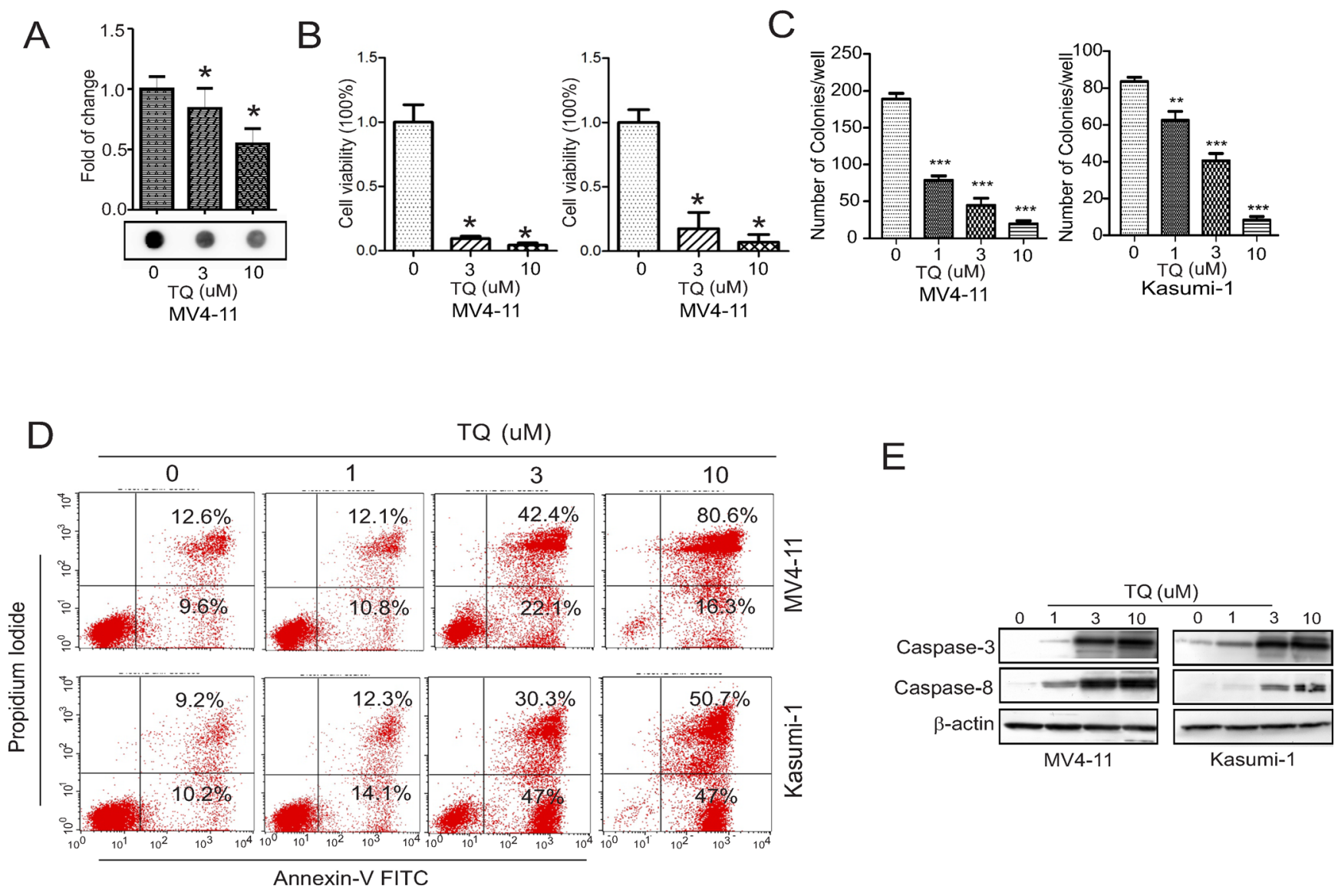

Figure 3: TQ inhibits DNA methylation and blocks leukemia growth in vitro. (A) Dotblot assays using anti-5mC in MV411 cells treated with TQ for 48 hours. Upper, graph is the quantification of dot intensities; lower, the representative image of dotblot. (B) Kasumi-1 and MV4-11 cells were treated with TQ for 48 hours and the cell viability was determined by CCK-8 assays. (C) Kasumi-1 and MV4-11 cells were treated with TQ for 6 hours and subjected to colony formation assays. (D) Flow cytometry assays for cell apoptosis in Kasumi-1 and MV4-11 cells treated with TQ for 48 hours. (E) Western blot in Kasumi-1 and MV4-11 cells treated with TQ for 24 hours. The data represent three independent experiments; In CCK-8 assays, the experiments were done twice independently with 8 replicates in total; Data are mean $\pm \mathrm{SD} ; * p<0.05, * * p<0.01, * * * p<0.001$. 
The mobile phases consisted of acetonitrile and $0.2 \%$ formic acid (FA) pumped at a flow rate of $0.2 \mathrm{~mL} /$ min. The tandem mass spectrometry data of TQ and the assay at the low range calibration curve were shown in Figure $5 \mathrm{~A}$ and $5 \mathrm{~B}$, respectively. The chromatogram of TQ with the internal standard in mouse plasma was shown in Figure 5C. Further, the linear range of calibration curve was from 0 to $1000(\mathrm{ng} / \mathrm{mL})$ in mobile phase solution and/ or mouse plasma. The lowest concentration of detection (LOD) of TQ in mouse plasma was $5 \mathrm{ng} / \mathrm{mL}$ and the lowest concentration of quantification (LOQ) was $10 \mathrm{ng} /$ $\mathrm{mL}$. The calibration curve of TQ and the corresponding recovered concentration and accuracy in mouse plasma were shown in Figure 6A-6C. These data showed a linear range of the assay between $0-1000 \mathrm{ng} / \mathrm{mL}$. The validation data showed that the percent of coefficient of variation $\mathrm{CV}$ and the accuracy values were $4.68 \%-9.19 \%$ and $95.5 \%$ $113 \%$ for the quality control (QC) concentrations of 10 , 100 , and $1000 \mathrm{ng} / \mathrm{mL}(n=6)$, respectively. In addition, we also performed the stability study of TQ in mouse plasma. The stability data revealed that the compound was stable at $-20^{\circ} \mathrm{C}$ under dim light condition, but not at $25^{\circ} \mathrm{C}$ and $37^{\circ} \mathrm{C}$. Thus, TQ is more stable in the dark and at cold temperature.

\section{Plasma pharmacokinetic profile of TQ after I.V. injection}

To determine the plasma pharmacokinetics of TQ, we administered TQ, which was dissolved in a mixture of ethanol, PEG400 and saline at the concentration of $9.0 \mathrm{mg} / \mathrm{mL}$, to the CDF1 male mice $(n=2$ mice per time point) via the tail vein at the dose of $30 \mathrm{mg} / \mathrm{kg} / \mathrm{mouse}$. Plasma samples were collected at the time points of 5, 10, $15,30,60,120$ and 180 min post i.v. injection and stored under $-80^{\circ} \mathrm{C}$. These plasma samples were mixed with Hesperitin followed by the addition of ethyl acetate. After centrifugation at $14000 \mathrm{rpm}$, the supernatant was dried by

A
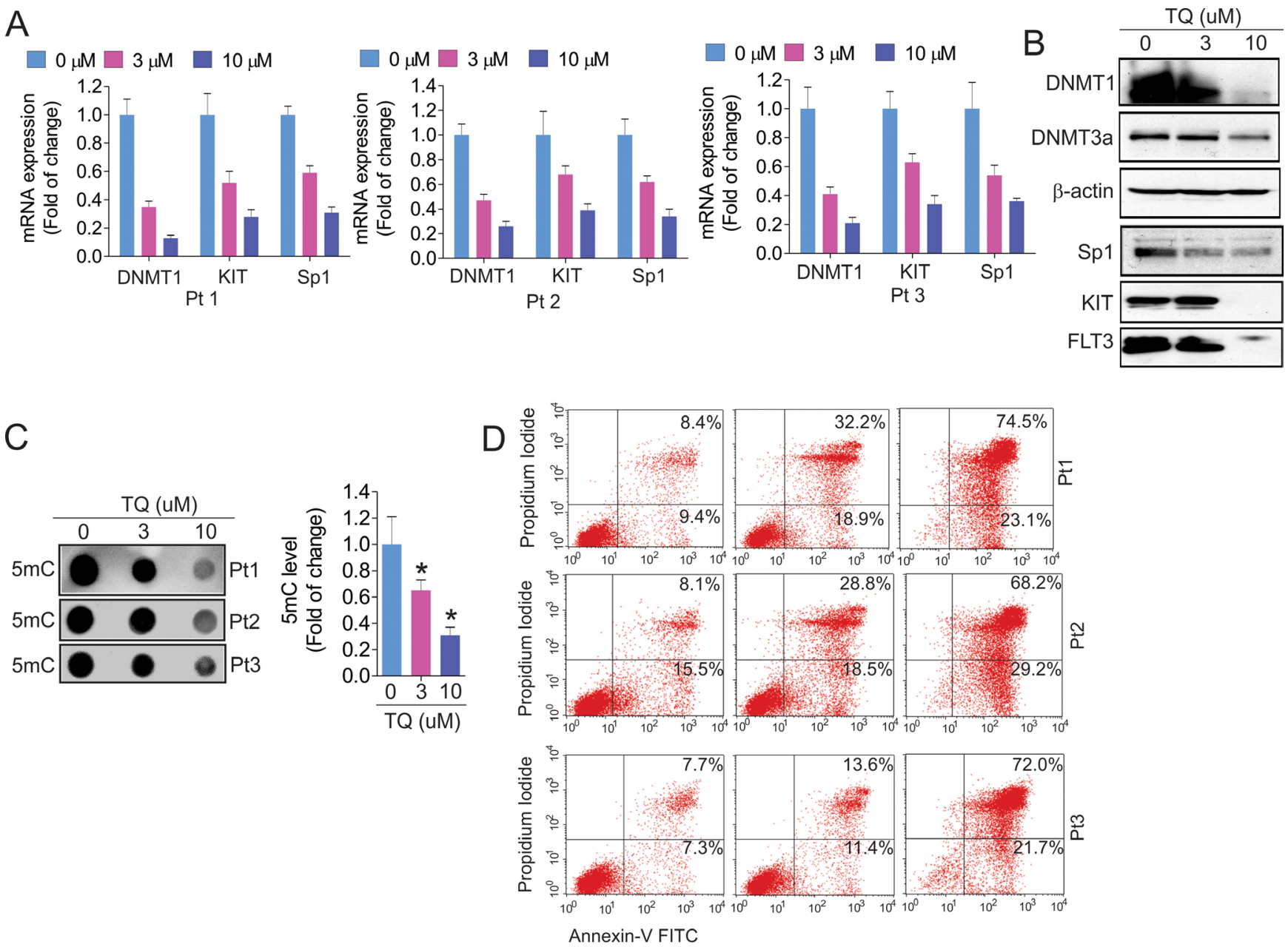

Figure 4: Exposure of leukemia primary cells to TQ leads to DNA demethylation and cell apoptosis. The primary cells from leukemia patients $(n=3)$ were exposed to TQ for 24 hours. (A) qPCR showing the expression of TQ target genes. (B) The treated cells from three patients were pooled together and subjected to Western blot. (C) Dotblot using anti-5 mC measuring the change of DNA methylation. Graph is the quantification of dot intensities. Data are mean $\pm \mathrm{SD} ;{ }^{*} p<0.05$. (D) Flow cytometry assays for cell apoptosis in primary cells. Note: Pt, patient. 
$\mathrm{N}_{2}$, and then reconstituted in mobile phase solution. The concentration of TQ in each plasma sample was assessed by LC/MS. As shown in Figure 7A-7C, we successfully detected a dynamic change of TQ in mouse plasma. It seems that the plasma concentration-time profile follows a multi-exponential decline, likely to be triphasic.

\section{TQ administration attenuates leukemia growth in mice}

To demonstrate the anti-leukemia activities of TQ in vivo, we first determined a tolerable dose in mouse model for in vivo administration. In these experiments, we administered TQ into C57BL/6 mice ( $n=10,4-6$ weeks old) by intravenous injection at the doses of 0,15 and $30 \mathrm{mg} / \mathrm{kg}$ at normal pressure. Mice treated with equal volume of PBS + ethanol were used as controls. The schedule was 2 doses per week and completed 6 doses in 3 weeks. We observed that $100 \%$ mortality in mice receiving $30 \mathrm{mg} / \mathrm{kg} \mathrm{TQ}, 30 \%$ mortality receiving $15 \mathrm{mg} / \mathrm{kg}$ and no mortality in control mice. Based on these results, we gave C57BL/6 mice $(n=3)$ one dose of $5 \mathrm{mg} / \mathrm{kg}$ TQ in PBS + ethanol 12 hour prior to i.v. injection of $\mathrm{C} 1498$ cells $(0.1$ $\times 10^{6}$ ) followed by 2 times of $5 \mathrm{mg} / \mathrm{kg} / 3$-day in the first week and 2 times of $10 \mathrm{mg} / \mathrm{kg} / 3$-day in the second week. The development of leukemic disease was monitored by the white blood cell count (not shown). We found that TQ administration induced leukemia regression, as indicated by the reversed splenomegaly (Figure 8A) and the inhibited leukemia growth in lungs and livers (Figure 8B and 8C). Collectively, TQ treatment impairs leukemia growth in vitro, ex vivo and in vivo in a mouse model of leukemia.

\section{DISCUSSION}

Thymoquinone (TQ) is the main lipid constituent of Nigella sativa (black cumin) and Monarda fistulosa, which are widely known and used herbal medicine. Many reports showed that TQ has potent antitumor activity in both in

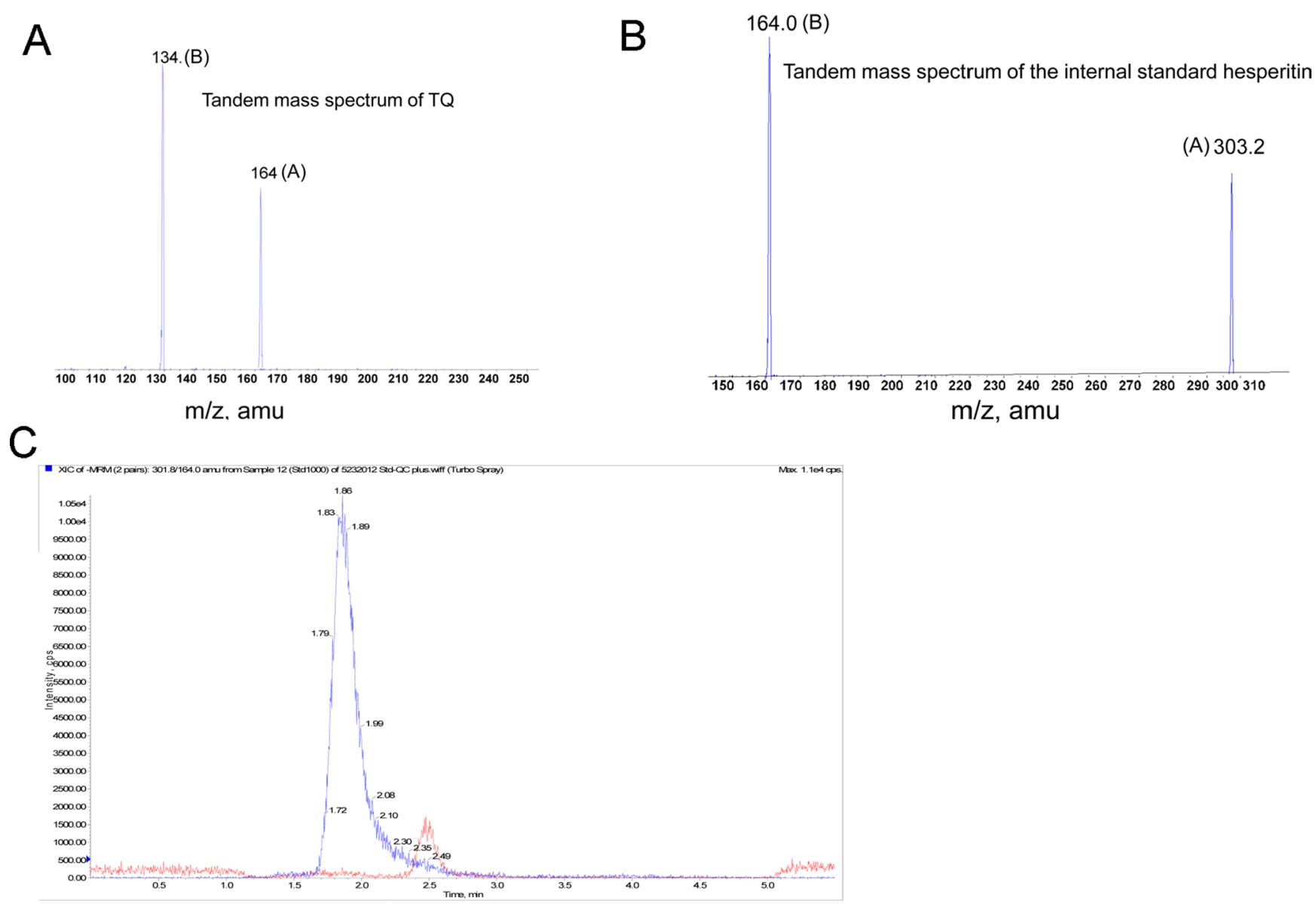

Figure 5: Sensitivity of the method at lower range standard curve. (A) The protonated molecular ion (A) of TQ at m/z 164.0 and the collision assisted dissociation daughter ion $(\mathrm{B}, \mathrm{m} / \mathrm{z}$ 134.1) of the protonated molecular ion. (B) The protonated molecular ion (B) of the Internal Standard Hesperitin at m/z 303.2 and the collision assisted dissociation daughter ion (B) of protonated molecular ion at $\mathrm{m} / \mathrm{z}$ 164.0. (C) The LC-MS/MS chromatogram of TQ and its I.S (Internal Standard) in mouse plasma. The retention time of TQ in mouse plasma is at about $2.5 \mathrm{~min}$, and that of the internal standard is about $1.99 \mathrm{~min}$. 

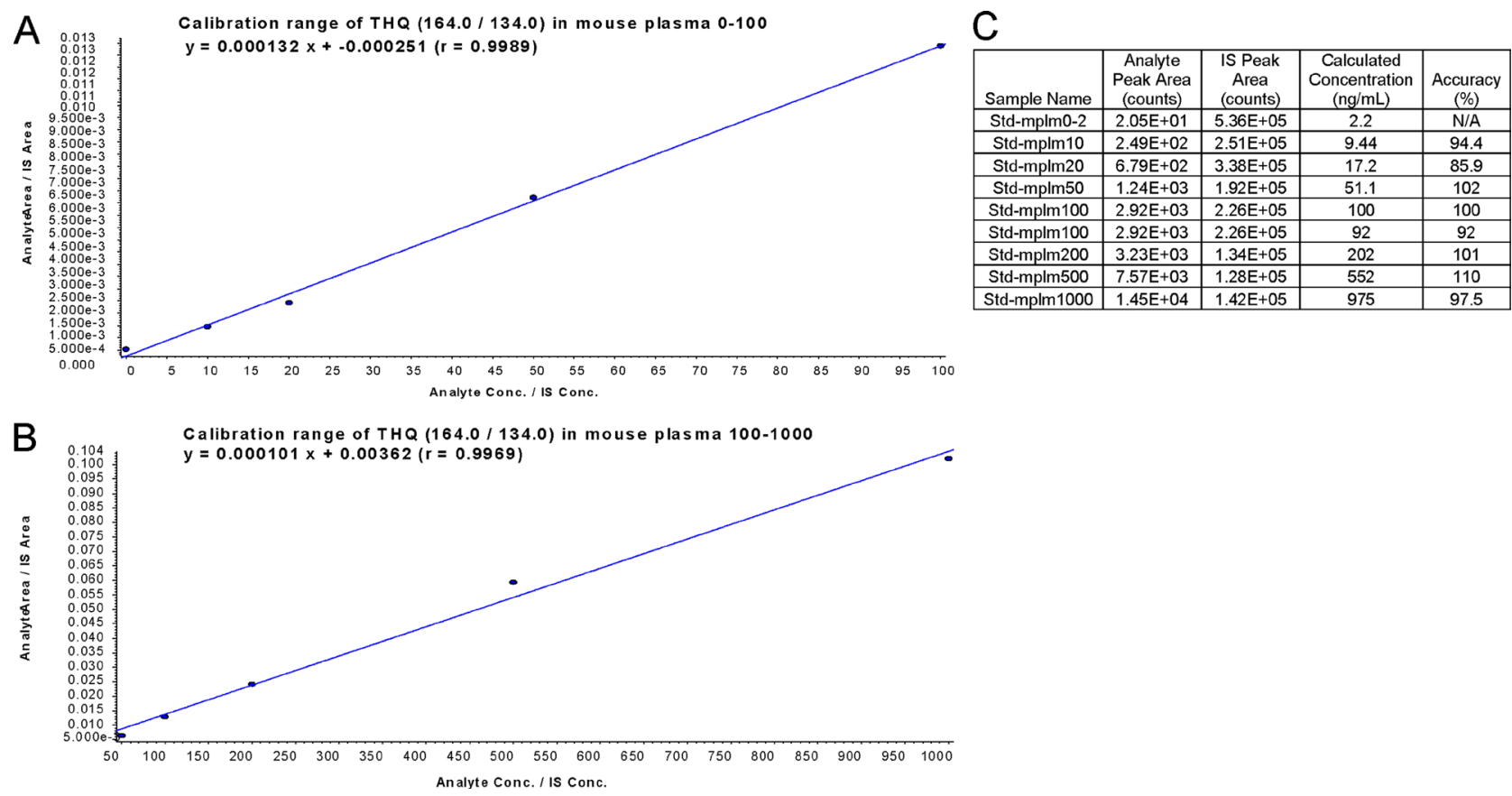

Figure 6: Calibration curve of TQ in mouse plasma. (A and B) Calibration range of TQ (THQ) at 0-100 ng (A) and 50-1000 ng (B) in mouse plasma. (C) Calculated value and accuracy of calibration curve.

A

\begin{tabular}{|c|c|c|c|}
\hline $\begin{array}{c}\text { Sample } \\
\text { ID }\end{array}$ & $\begin{array}{c}\text { Analyte Peak } \\
\text { Area (counts) }\end{array}$ & $\begin{array}{c}\text { IS Peak Area } \\
\text { (counts) }\end{array}$ & $\begin{array}{c}\text { Calculated } \\
\text { Concentration } \\
\text { (ng/mL) }\end{array}$ \\
\hline $5 \mathrm{~min}-1$ & $2.96 \mathrm{E}+04$ & $3.00 \mathrm{E}+06$ & 1070 \\
\hline $5 \mathrm{~min}-2$ & $3.48 \mathrm{E}+04$ & $3.20 \mathrm{E}+06$ & 1170 \\
\hline $10 \mathrm{~min}-1$ & $1.90 \mathrm{E}+04$ & $2.55 \mathrm{E}+06$ & 839 \\
\hline $10 \mathrm{~min}-2$ & $2.97 \mathrm{E}+04$ & $3.52 \mathrm{E}+06$ & 937 \\
\hline $15 \mathrm{~min}-1$ & $1.47 \mathrm{E}+04$ & $3.41 \mathrm{E}+06$ & 534 \\
\hline $15 \mathrm{~min}-2$ & $1.24 \mathrm{E}+04$ & $2.22 \mathrm{E}+06$ & 659 \\
\hline $30 \mathrm{~min}-1$ & $7.62 \mathrm{E}+03$ & $3.32 \mathrm{E}+06$ & 338 \\
\hline $30 \mathrm{~min}-2$ & $1.22 \mathrm{E}+04$ & $3.09 \mathrm{E}+06$ & 498 \\
\hline $60 \mathrm{~min}-1$ & $2.10 \mathrm{E}+03$ & $3.17 \mathrm{E}+06$ & 179 \\
\hline $60 \mathrm{~min}-2$ & $2.68 \mathrm{E}+03$ & $3.24 \mathrm{E}+06$ & 195 \\
\hline $120 \mathrm{~min}-1$ & $1.17 \mathrm{E}+03$ & $2.09 \mathrm{E}+06$ & 169 \\
\hline $120 \mathrm{~min}-2$ & $7.38 \mathrm{E}+02$ & $3.14 \mathrm{E}+06$ & 137 \\
\hline $180 \mathrm{~min}-1$ & $1.05 \mathrm{E}+02$ & $1.65 \mathrm{E}+06$ & 26.3 \\
\hline $180 \mathrm{~min}-2$ & $1.05 \mathrm{E}+02$ & $3.57 \mathrm{E}+06$ & 11.5 \\
\hline
\end{tabular}

B

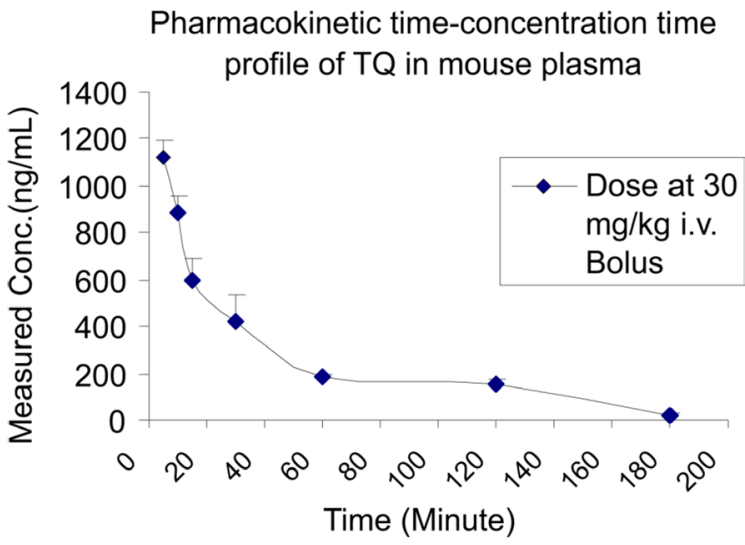

C

\begin{tabular}{|c|c|c|c|c|c|}
\hline Sample ID & $\begin{array}{c}\text { Conc. } \\
(\mathrm{ng} / \mathrm{mL})-1\end{array}$ & $\begin{array}{c}\text { Conc. } \\
(\mathrm{ng} / \mathrm{mL})-2\end{array}$ & $\begin{array}{c}\text { Mean } \\
\text { Conc. }(\mathrm{ng} / \mathrm{mL})\end{array}$ & Difference & $\begin{array}{c}\text { Delta } \\
(\%)\end{array}$ \\
\hline $5 \mathrm{~min}$ & 1070 & 1170 & 1120 & 70.71 & 6.31 \\
\hline $10 \mathrm{~min}$ & 839 & 937 & 888 & 69.30 & 7.80 \\
\hline $15 \mathrm{~min}$ & 534 & 659 & 596.5 & 88.39 & 14.82 \\
\hline $30 \mathrm{~min}$ & 338 & 498 & 418 & 113.14 & 27.07 \\
\hline $60 \mathrm{~min}$ & 179 & 195 & 187 & 11.31 & 6.05 \\
\hline $120 \mathrm{~min}$ & 169 & 137 & 153 & 22.63 & 14.79 \\
\hline $180 \mathrm{~min}$ & 26.3 & 11.5 & 18.9 & 10.47 & 55.37 \\
\hline
\end{tabular}

Figure 7: Plasma pharmacokinetic profile of TQ. (A) The measured concentrations of TQ in CDF1 mouse plasma. (B) Pharmacokinetic concentration-time profiles of TQ in CDF1 mice ( $n=2$ mice/group) at $30 \mathrm{mg} / \mathrm{kg}$. Data are mean $\pm \mathrm{SD}$ of each time point. (C) The calculated concentrations of TQ in CDF1 mouse plasma. TQ was administered into the mice at the dose of $30 \mathrm{mg} / \mathrm{kg} / \mathrm{mouse}$. The mice were sacrificed at 5, 10, 15, 30, 60, 120 and 180 min post-injection. 
vitro and in vivo for multiple types of cancer [32], but few studies focused on its potential anti-leukemia actions. Importantly, the molecular mechanisms underlying the anti-cancer activity of TQ and the methods to determine TQ pharmacokinetics in mouse plasma remain largely unexplored. In the current study, we present compelling evidence that TQ displays strong anti-leukemia activity in vitro, in leukemia patient primary cells and in a mouse model of leukemia. We identified DNMT1-assoicated DNA methylation as a hitherto unknown molecular rule mediating the anti-leukemia actions of TQ. Additionally, we have developed a LC-MS/MS method, which was validated for linearity and reproducibility, and successfully detected a dynamic change of TQ in mouse plasma after i.v. administration. Our findings shed new light on the mechanisms of TQ anti-cancer actions, providing a sound rationale in clinical trials for using TQ as a novel DNA hypomethylating agent to enhance the therapeutic index of typical DNA methylation inhibitors. Our results also offer an efficient method and platform for characterization of TQ pharmacokinetics that is critical for future clinical research.

Due to the significantly lower cytotoxicity to normal cells [32], TQ could be a promising anti-cancer drug by itself or in combination with other agents. To extrapolate it as a targeted therapy drug, the key is to uncover genes/signaling pathways that are responsible for TQ-induced cancer cell killing. While literature search has identified multiple mechanisms $[32,33]$, in the present study we shifted our attention to DNA methylation machinery. This is because 1) aberrant DNA methylation is a well-documented hallmark of cancers [34-36], 2) the therapeutic effects from typical DNA hypomethylating agents are limited [8, 37], 3) our previous study revealed that phytochemical compounds, such as curcumin, inhibit DNA methylation [25], and TQ is a phytochemical compound, and 4) multiple investigations demonstrated that TQ executes anticancer actions largely through NFkB signaling [38-41], which functions as a upstream regulator for many genes, including DNMT1 $[1,2,24]$. Indeed, we present evidence that TQ binds to the DNMT1 catalytic pocket, and dose-dependently suppresses DNMT1 methylation activity. We demonstrated that TQ incubation leads to downregulation of DNMT1, which, mechanistically, takes place through the disruption of Sp1/NFkB complex in the DNMT1 gene promoter, and decrease of DNA methylation. Collectively, our findings support the hypothesis that TQ induces DNA demethylation by both binding DNMT1 protein and suppressing DNMT1 gene expression, which is similar to the mechanism of curcumin $[25,42]$, but different from that of decitabine requiring incorporation into newly synthesized DNA without obvious changes of DNMT1 gene transcription. These discoveries are not only in

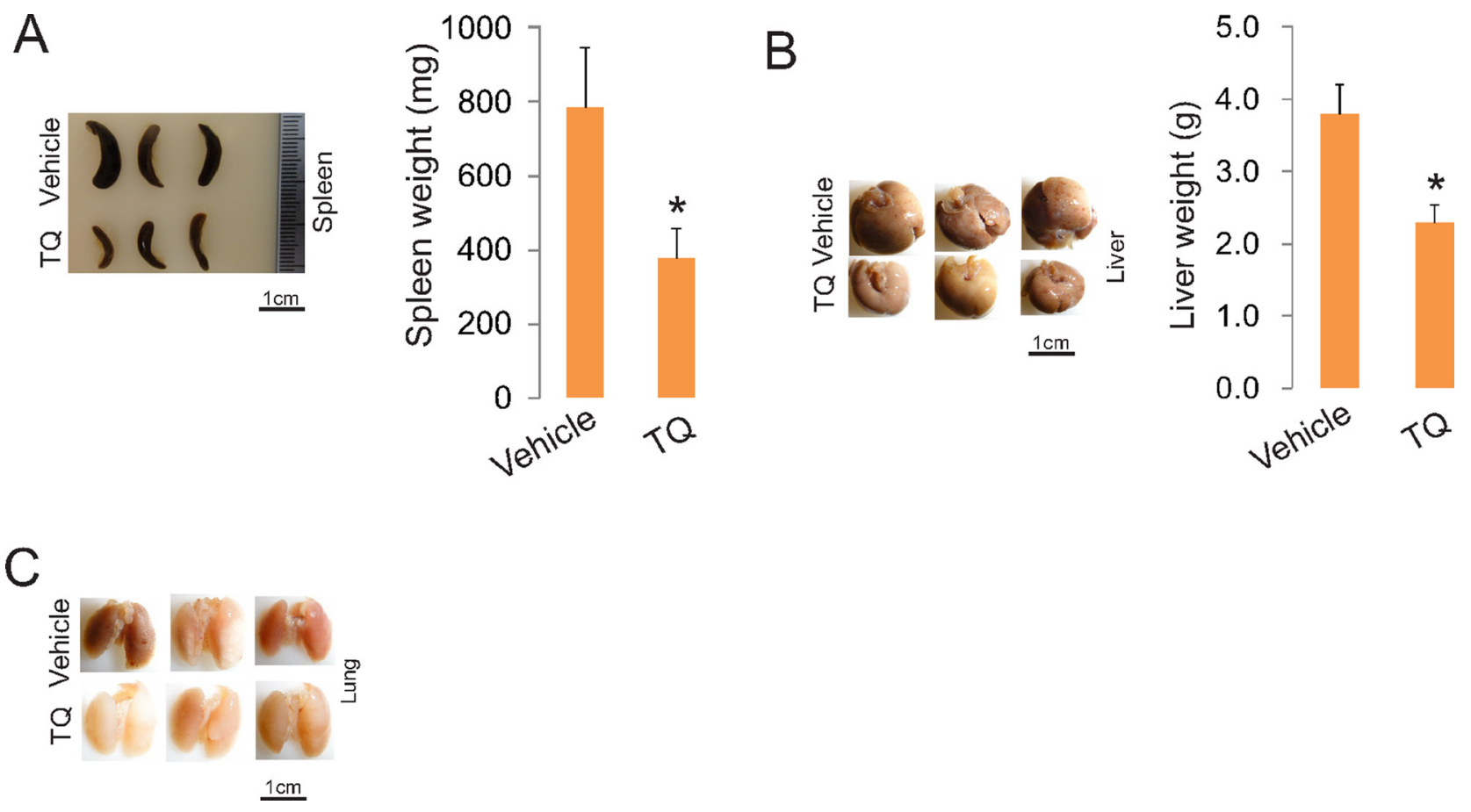

Figure 8: TQ administration inhibits leukemia growth in vivo. C1498 cells $\left(0.1 \times 10^{6}\right)$ were intravenously injected into C57BL/6 mice ( $n=3$ mice/group). One dose of $5 \mathrm{mg} / \mathrm{kg}$ TQ was given to these mice 12 hour prior to leukemia cell injection, which was followed by 2 times of $5 \mathrm{mg} / \mathrm{kg} / 3$-day in the first week and 2 times of $10 \mathrm{mg} / \mathrm{kg} / 3$-day in the second week. The experiments were terminated in three weeks and the organs were harvested. Left, external view of spleens, livers and lungs; right, graphs are the quantification of organ weight $(* p<0.05)$. 
agreement with the documented role of NFkB as a central mediator of TQ anti-cancer actions [38-41] and a direct/ indirect regulator of DNA methylation [1, 2, 24, 28], but also support DNMT1-associated DNA methylation as a new pharmacological endpoint of leukemia cells in response to TQ exposure as well as a common molecular rule underlying phytochemical compound-mediated cell death. To deepen insight into TQ's DNA hypomethylating activities for clinical implications, it is important for future studies to systematically define genes that are crucial for cancer pathogenesis and epigenetically reactivated by TQ treatment in distinct cancer cell/animal models, and correlates the findings with the progression of cancerous lesions. In addition, the exact binding model of TQ to DNMT1 remains unknown. Further exploration of the mode of binding to DNMT1 catalytic domain using mass spectrometry, structural analog probes, and enzymatic kinetics are warranted.

Considering that $\mathrm{Sp} 1 / \mathrm{NFkB}$ is also involved in the regulation of receptor tyrosine signaling [27], we examined the changes of two receptor tyrosine kinases, KIT and FLT3, which play a pivotal role in leukemia pathogenesis [27, 31, 43]. We show that TQ treatment significantly impairs the expression of KIT and FLT3, leading to the dephosphorylation of their downstream effectors, such as STAT5 and AKT, in cell lines and patient blasts. These findings not only agree with previous findings showing that tyrosine kinase signaling represents one of various molecular rules behind TQ-impaired cancer cell growth [44], but also add new members to the TQtargeted kinase family. Although further demonstrations are necessary, inactivation of KIT and FLT3 signaling by TQ may occur via their gene downregulation resulting from TQ-disrupted Sp1/NFkB functions. This mechanism is different from that of classical KIT and FLT3 inhibitors that competitively binds their enzymatic centers. Thus, these discoveries motivate us to consider a combination trial between TQ and inhibitors for KIT and FLT3 signaling in ongoing studies for improving therapeutic outcomes in leukemia.

\section{MATERIALS AND METHODS}

\section{Cell lines and chemicals}

Cell lines, Kasumi-1, MV4-11, THP-1 and ML1, were purchased from The American Type Culture Collection (Manassas, VA), and maintained in RPMI 1640 medium, supplemented with $50 \mu \mathrm{g} / \mathrm{mL}$ streptomycin, $50 \mathrm{IU} / \mathrm{mL}$ penicillin plus $20 \%$ (Kasumi- 1 ) or $10 \%$ (others) fetal bovine serum (FBS) at $37^{\circ} \mathrm{C}$ in $95 \%$ humidified atmosphere with $5 \% \mathrm{CO}_{2}$ in air. Decitabine and thymoquinone (Sigma-Aldrich, MO) were dissolved in PBS or DMSO, respectively, as a stock solution, sterilized by filtration through a $0.22 \mu \mathrm{m}$ syringe filter and stored at $-80^{\circ} \mathrm{C}$.

\section{Human DNMT1 homology modeling}

The homology model of human DNMT1 catalytic domain was built with the crystal structure of bacterial modification methylase (Hhal) catalytic domain (PDB ID: 4MHT) as the modeling template. The 478 amino acids (AA 1139-1616) of DNMT1 were aligned against 327 residue thal methylase catalytic domain by a combination of CLUSTALW and Smith-waterman methods. The Nand C-terminal sequences align well with the template and the middle sequence has little homology between the two proteins. The two aligned regions were modeled using MODELLER v8 [45]. The resulting structure was minimized together with cofactor SAH and flipped cytosine substrate plus $15 \AA$ truncated octahedron TIP3P water box by using AMBER9 [46].

\section{Docking of thymoquinone}

AutoDock version 4.0 [47] was used for the docking simulation. We selected the Lamarckian genetic algorithm (LGA) for ligand conformational searching because it has enhanced performance relative to simulated annealing or the simple genetic algorithm. For TQ, all hydrogens were added and Gasteiger charges were assigned, then non-polar hydrogens were merged. $80 \times 100 \times 703$-D affinity grids centered on the empty binding site with $0.375 \AA$ spacing were calculated for each of the following atom types: a) protein: A (aromatic C), C, HD, N, NA, OA, SA; b) ligand: $\mathrm{C}, \mathrm{A}, \mathrm{OA}, \mathrm{e}$ (electrostatic) and $\mathrm{d}$ (desolvation) using Autogrid. The translation, rotation and internal torsions of the ligand are defined as its state variables and each gene represents a state variable. LGA adds local minimization to the genetic algorithm, enabling modification of the gene population. The docking parameters were as follows: trials of 100 dockings, population size of 250, random starting position and conformation, translation step ranges of 2.0 $\AA$, rotation step ranges of $50^{\circ}$, elitism of 1 , mutation rate of 0.02 , crossover rate of 0.8 , local search rate of 0.06 , and 1 million energy evaluations. Final docked conformations were clustered using a tolerance of $1.5 \AA$ root-meansquare deviations (RMSD).

\section{In vitro enzymatic activity assays}

The DNMT1 enzymatic assays were performed as previously reported [25]. Briefly, a double strand DNAoligonucleotide containing CCGG was labeled with 3 '-biotin in one strand and 3'-digoxigenin-NHS ester in its complementary strand. This labeled probe was used as a substrate for M. SssI and the enzymatic assay was carried out in a solution containing SAM and the endonuclease HpaII. After cleavage by a HpaII, the 3'-digoxigeninNHS ester was removed and no detectable fluorescence signal was detected, when anti-digoxigenin-AP antibody and the substrate Attophos were added to the solution. In 
contrast, when the CCGG sequence was methylated to $\mathrm{CC}^{\mathrm{m}} \mathrm{GG}$, cleavage activity of HpaII was inhibited and the 3 '-digoxigenin-NHS ester was maintained leading to the generation of fluorescence signal. The methylation level of DNA probe was positively correlated with the intensity of the assay fluorescence signal, thereby the enzymatic activity of M. SssI.

\section{Quantification of DNA methylation}

Genomic DNA was prepared using a DNeasy Tissue Kit (QIAGEN, Maryland). About $2 \mu \mathrm{g}$ DNA was subjected to Dotblot using $5 \mathrm{mC}$ antibody as previously described [1-3, 48].

\section{Colony formation and flow cytometry assays}

Methylcellulose colony formation assays were carried out in MethoCult ${ }^{\circledR}$ mixture (Stem Cell Technologies) as previously described [1-3, 48]. Colonies were scored 7-14 days. Trypan blue exclusion was used to assess cell viability. Cell apoptosis assays were performed using Annexin V-PE Apoptosis Detection Kit I (BD PharmingenTM, San Diego, CA) according to the manufacturer's instruction, and followed by flow cytometry analysis.

\section{Cell counting Kit-8 (CCK-8) assays}

After various treatments, the viable Kasumi-1 and MV4-11 cells were counted by the CCK-8 assay Kits (Dojindo Laboratories, Kumamoto, Japan) following the manufacturers' instruction. Four wells were sampled per each experimental group in each experiment. Averages were reported as \pm Standard Deviation (SD).

\section{Western blot}

After various treatment, total protein lysates were prepared in $1 \times$ lysis buffer [20 mM HEPES ( $\mathrm{pH} 7.0)$, $150 \mathrm{mM} \mathrm{NaCl}$ and $0.1 \% \mathrm{NP} 40$ ] supplemented with 1 mM PMSF (Sigma Aldrich), 1× Phosphatase Inhibitor Cocktail 2 and 3 (Sigma Aldrich), and $1 \times$ protease inhibitors (protease inhibitor cocktail set III, CalbiochemNovabiochem, San Diego, CA) and subjected to Western blot as previously described [1-3]. Equivalent gel loading was confirmed by incubating with $\beta$-actin antibody. The antibodies used are DNMT3a, Sp1 and $\beta$-actin (Santa Cruz Biotechnology, CA); DNMT1 and DNMT3b (Abcam, Cambridge, MA); KIT, FLT3, p-STAT5, STAT5, p-AKT, AKT, caspase-3 and caspase-8 (Cell Signaling Technology, Danvers, MA).

\section{Electrophoretic mobility-shift assays (EMSA)}

Complementary oligonucleotides were synthesized (Sigma), annealed and labeled with ${ }^{32} \mathrm{P}-\mathrm{dCTP}$ and Klenow. Nuclear extracts were prepared from MV4-
11 cells using Nuclear Extract Kit (Active Motif) in the presence of proteinase inhibitor cocktail (Roche Diagnostics, IN). EMSA with nuclear extracts and ${ }^{32} \mathrm{P}$-labeled probes were performed as described [24, 27-29, 49]. The oligo sequences used are: DNMT1/ Sp1/1F: 5'-GGGCTCCGCGTGGGGGGGGTGTGTGCC CGCCTTGCGC-3'; DNMT1/Sp1/1R: 5'-GCGCAAGGCG GGCACACACCCCCCCCACGCGGAG-3'.

\section{Chromatin immunoprecipitation (ChIP)}

ChIP assays were performed as described previously [3, 27, 30] using EZ-ChIP Assay Kit (Millipore, Billerica, MA). Briefly, about $2 \times 10^{6}$ cells were cross-linked with $1 \%$ formaldehyde (Sigma-Aldrich), resuspended in $1 \%$ SDS lysis buffer and sonicated. After being precleared with protein $\mathrm{G}$ agarose, the lysates were immunoprecipitated by $5 \mu \mathrm{g}$ antibodies for NFkB (Abcam) or anti-Sp1 (Santa Cruz Biotechnology). ChIP DNA was quantified by qPCR with $\mathrm{SYBR}^{\circledR}$ Green PCR Master Mix. Fold change in binding was normalized by the respective input DNA. The primers are: DNMTCHF 5'-GTATCG CCTCTCTCCGTT-3'; DNMTCHR 5'-TCGGAGGCT TCAGCAGAC-3'.

\section{RNA isolation and quantitative PCR (qPCR)}

According to the manufacturer's instructions, total RNA was isolated using miRNeasy Mini Kit (Qiagen, Valencia, CA) and cDNA synthesis was carried out using SuperScript ${ }^{\circledR}$ III First-Strand Synthesis System (Invitrogen). The gene expression was assessed by $\mathrm{SYBR}^{\circledR}$ Green qPCR and normalized by $18 \mathrm{~S}$ levels. For miRNA expression, qRT-PCR was performed by TaqMan MicroRNA Assays (Applied Biosystems, CA) and normalized by $U 44 / 48$ levels.

\section{Development of LC-MS/MS}

\section{Sample preparation}

To ensure stabilized condition for TQ during sample preparation, all samples were prepared under minimized light condition and in ice. Specifically, TQ was dissolved in acetonitrile (ACN) to make stock solutions at $1 \mathrm{mg}$ / $\mathrm{mL}$. The standard curve solutions of this analyte were prepared by serial dilution from the stock solutions in 50\% acetonitrile to obtain the concentrations ranging from 0 to $1000 \mathrm{ng} / \mathrm{mL}$. To test the linearity of this standard curve, $10 \mu \mathrm{L}$ of the appropriate concentration range (2-50ng/ $\mathrm{mL}$ ) of the intermediated stock solutions were spiked into $100 \mu \mathrm{L}$ of mobile phase which consists of $50 \% \mathrm{ACN}$ in $0.2 \%$ formic acid. The mixture was vortex-mixed for 30 seconds and a $20 \mu \mathrm{L}$ aliquot was injected into the LCMS/MS system. In order to prepare the calibration curve sample, $10 \mu \mathrm{L}$ of various standard curve solutions at 10 , $20,50,100,200,500,1000,2000,5000$ and $10000 \mathrm{ng} /$ 
$\mathrm{mL}$ in $50 \% \mathrm{ACN}$ was spiked into $100 \mu \mathrm{L}$ mouse plasma containing $1000 \mathrm{ng} / \mathrm{mL}$, then to the mixture was added 1 $\mathrm{mL}$ ethyl acetate and the mixture was vigorously vortexmixed for 30 second followed by centrifugation at 12000 rpm for $3 \mathrm{~min}$. The supernatant was then transferred into a new glass tube and dried by a stream of $\mathrm{N}_{2}$. The residue was reconstituted with $100 \mu \mathrm{L}$ mobile phase $(50 \% \mathrm{ACN}$ and $0.2 \%$ formic acid), and a $20 \mu \mathrm{L}$ aliquot was injected into an API-3000 triple quadruple mass spectrometer.

\section{LC-MS/MS conditions}

An Applied Biosystems Sciex API 3000 triple quadruple mass spectrometer (Applied Biosystems Sciex, Ontario) equipped with an electrospray ionization (ESI) source was used for mass analysis and detection. The detector was operated at unit resolution in MRM mode using the transitions from the protonated molecular ions to product ions at $\mathrm{m} / \mathrm{z} 164.00 / 134.10$ for TQ.

A SIL-10ADvp Shimadzu HPLC system (Shimadzu, Columbia, MD) consisting of system controller, degasser, binary pump and auto-sampler was used for solvent and sample delivery. The chromatographic separation was performed using a Beta Basic C8 column $(2.1 \mathrm{~mm} \times 50$ $\mathrm{mm}, 5 \mu \mathrm{m}$ ) coupled with a Beta Basic C8 guard column $(2.1 \mathrm{~mm} \times 10 \mathrm{~mm}, 5 \mu \mathrm{m})$. The mobile phases consisted of acetonitrile and $0.2 \%$ formic acid (FA) pumped at a flow rate of $0.2 \mathrm{~mL} / \mathrm{min}$.

\section{Plasma PK study of TQ}

\section{Mouse treatment, plasma sample preparation and LC/ MS analysis}

CDF1 male mice (4-6 weeks old) were purchased from Harlan (Indianapolis, IN). Upon receipt, mice were acclimated before the study. All animal experiments were carried out according to a protocol approved by the Institutional Animal Care and Use Committee at The Ohio State University. The TQ solution was freshly prepared at the concentration of $9.0 \mathrm{mg} / \mathrm{mL}$ in the formulation of a mixture of ethanol, PEG400 and saline and the formulated solution $(\sim 100 \mu \mathrm{L}$ or less $)$ was administered to the mice via the tail vein at the dose of $30 \mathrm{mg} / \mathrm{kg}$ for each. Mice were sacrificed at the time points of 5, 10, 15, 30, 60, 120 and 180 min post i.v. injection. Each time point had 2 mice. Plasma samples were collected immediately at the time points mentioned above and frozen in $\mathrm{a}-80^{\circ} \mathrm{C}$ freezer until further analysis. The calibration curve was constructed in the concentration range of $0,5,10,20,50,100,200,500$, and $1000 \mathrm{ng} / \mathrm{mL}$ with QC in duplicates and the plasma PK samples were prepared in the same way as the calibration curve samples. Briefly, $100 \mu \mathrm{L}$ of mouse plasma sample was mixed with $10 \mu \mathrm{L}$ of $10 \mu \mathrm{g} / \mathrm{mL}$ of Hesperitin; then 1 $\mathrm{mL}$ ethyl acetate was added, followed by vigorous vortex mixing and the solutions centrifuged at $14000 \mathrm{rpm}$. The supernatant was separated and dried under $\mathrm{N}_{2}$, and then reconstituted in mobile phase solution. The concentration of
TQ in each plasma sample was measured by LC/MS. The concentration-time data were analyzed by Excel software.

\section{Determination of the maximum tolerated dose}

C57BL/6 mice (male, 4 -6 weeks old) were purchased from Harlan (Indianapolis, IN). All animal experiments were carried out according to a protocol approved by the Institutional Animal Care and Use Committee at The Ohio State University. In these experiments, TQ was dissolved in ethanol, diluted in PBS and administered into mice by intravenous (i.e., through the tail vein) injection in a small volume $(0.2 \mathrm{ml})$ at normal pressure. Mice treated with equal volume of PBS (+ethanol) were used as controls. 10 mice per group was used and the drug doses were 0,15 and $30 \mathrm{mg} / \mathrm{kg}$. The administration schedule was 2 doses per week and completed 6 doses in 3 weeks.

\section{Leukemogenesis in mice}

C57BL/6 mice (female, 4-6 weeks old) were purchased from The Jackson Laboratory (Bar Harbor, ME). All animal studies were performed with approval from the University of Minnesota Institutional Laboratory Animal Care and Use Committee. The C1498 cells $\left(0.1 \times 10^{6}\right)$, a murine AML cell line, were intravenously injected into the C57BL/6 mice $(n=3)$. One dose of $5 \mathrm{mg} / \mathrm{kg}$ TQ was given to C57BL/6 mice 12 hour prior to C1498 cell injection, followed by 2 times of $5 \mathrm{mg} / \mathrm{kg} / 3$ day in the first week and 2 times of $10 \mathrm{mg} / \mathrm{kg} / 3$-day in the second week. The development of leukemic disease was monitored by the white blood cell count. The experiments were terminated in three weeks. Following sacrifice, the spleens, livers and lungs were harvested and weighted.

\section{Leukemia patients}

The current study was approved by the University Institutional Review Board and conducted in accordance with the Declaration of Helsinki. All patients signed informed consent to store and use their leukemia tissue for discovery studies as part of Hematologic Malignancy Tissue Bank. Peripheral blood mononuclear cells (PBMCs) were isolated from whole blood using FicollPaque $^{\mathrm{TM}}$ and stored at $-90^{\circ} \mathrm{C}$. Samples were later thawed and recovered in RPMI 1640 medium with 20\% FBS $[1,3]$ for 6 hours prior to treatment.

\section{Statistical analysis}

The quantification for target changes was performed using the Student's t test. All statistical analyses were done using GraphPad Prism 5.0. Differences were considered statistically significant at $P<0.05$. All $P$ values were determined by unpaired, two-tailed Student's $t$-test. 


\section{ACKNOWLEDGMENTS AND FUNDING}

This work was supported partially by the Hormel Institution Fund, Prairie Pharms LLC Fund, National Cancer Institute Grants (R01CA149623, R21CA155915, 5P30CA077598-18), Minnesota Masonic Charities and the Killebrew-Thompson Memorial Fund.

\section{CONFLICTS OF INTEREST}

Dr. Eric Weaver is the Chief Executive Officer (CEO) of Prairie Pharms LLC; The other authors state no conflicts of interest.

\section{REFERENCES}

1. Yan F, Shen N, Pang JX, Zhang YW, Rao EY, Bode AM, Al-Kali A, Zhang DE, Litzow MR, Li B, Liu SJ. Fatty acidbinding protein FABP4 mechanistically links obesity with aggressive AML by enhancing aberrant DNA methylation in AML cells. Leukemia. 2016.

2. Shen N, Yan F, Pang J, Wu LC, Al-Kali A, Litzow MR, Liu S. A nucleolin-DNMT1 regulatory axis in acute myeloid leukemogenesis. Oncotarget. 2014; 5:5494-5509. doi: 10.18632/oncotarget.2131.

3. Gao XN, Yan F, Lin J, Gao L, Lu XL, Wei SC, Shen N, Pang JX, Ning QY, Komeno Y, Deng AL, Xu YH, Shi JL, et al. AML1/ETO cooperates with HIF1alpha to promote leukemogenesis through DNMT3a transactivation. Leukemia. 2015; 29:1730-1740.

4. Herman JG, Jen J, Merlo A, Baylin SB. Hypermethylationassociated inactivation indicates a tumor suppressor role for p15INK4B. Cancer Res. 1996; 56:722-727.

5. Issa JP, Zehnbauer BA, Civin CI, Collector MI, Sharkis SJ, Davidson NE, Kaufmann SH, Baylin SB. The estrogen receptor $\mathrm{CpG}$ island is methylated in most hematopoietic neoplasms. Cancer Res. 1996; 56:973-977.

6. Issa JP, Kantarjian HM, Kirkpatrick P. Azacitidine. Nat Rev Drug Discov. 2005; 4:275-276.

7. Oki Y, Aoki E, Issa JP. Decitabine--bedside to bench. Crit Rev Oncol Hematol. 2007; 61:140-152.

8. Yan F, Shen N, Pang J, Molina JR, Yang P, Liu S. The DNA Methyltransferase DNMT1 and Tyrosine-Protein Kinase KIT Cooperatively Promote Resistance to 5-Aza-2'deoxycytidine (Decitabine) and Midostaurin (PKC412) in Lung Cancer Cells. J Biol Chem. 2015; 290:18480-18494.

9. Yoo CB, Jeong S, Egger G, Liang G, Phiasivongsa P, Tang C, Redkar S, Jones PA. Delivery of 5-aza-2'deoxycytidine to cells using oligodeoxynucleotides. Cancer Res. 2007; 67:6400-6408.

10. Ghoshal K, Datta J, Majumder S, Bai S, Kutay H, Motiwala T, Jacob ST. 5-Aza-deoxycytidine induces selective degradation of DNA methyltransferase 1 by a proteasomal pathway that requires the KEN box, bromoadjacent homology domain, and nuclear localization signal. Mol Cell Biol. 2005; 25:4727-4741.
11. Gali-Muhtasib H, Roessner A, Schneider-Stock R. Thymoquinone: a promising anti-cancer drug from natural sources. Int J Biochem Cell Biol. 2006; 38:1249-1253.

12. Liu Z, Liu S, Xie Z, Pavlovicz RE, Wu J, Chen P, Aimiuwu J, Pang J, Bhasin D, Neviani P, Fuchs JR, Plass C, Li PK, et al. Modulation of DNA methylation by a sesquiterpene lactone parthenolide. J Pharmacol Exp Ther. 2009; 329:505-514.

13. Worthen DR, Ghosheh OA, Crooks PA. The in vitro anti-tumor activity of some crude and purified components of blackseed, Nigella sativa L. Anticancer Res. 1998; 18:1527-1532.

14. Houghton PJ, Zarka R, de las Heras B, Hoult JR. Fixed oil of Nigella sativa and derived thymoquinone inhibit eicosanoid generation in leukocytes and membrane lipid peroxidation. Planta Med. 1995; 61:33-36.

15. Mansour MA, Nagi MN, El-Khatib AS, Al-Bekairi AM. Effects of thymoquinone on antioxidant enzyme activities, lipid peroxidation and DT-diaphorase in different tissues of mice: a possible mechanism of action. Cell Biochem Funct. 2002; 20:143-151.

16. Gali-Muhtasib HU, Abou Kheir WG, Kheir LA, Darwiche N, Crooks PA. Molecular pathway for thymoquinone-induced cell-cycle arrest and apoptosis in neoplastic keratinocytes. Anti-cancer drugs. 2004; 15:389-399.

17. Shoieb AM, Elgayyar M, Dudrick PS, Bell JL, Tithof PK. In vitro inhibition of growth and induction of apoptosis in cancer cell lines by thymoquinone. Int J Oncol. 2003; 22:107-113.

18. Roepke M, Diestel A, Bajbouj K, Walluscheck D, Schonfeld P, Roessner A, Schneider-Stock R, GaliMuhtasib H. Lack of p53 augments thymoquinone-induced apoptosis and caspase activation in human osteosarcoma cells. Cancer Biol Ther. 2007; 6:160-169.

19. El Mezayen R, El Gazzar M, Nicolls MR, Marecki JC, Dreskin SC, Nomiyama H. Effect of thymoquinone on cyclooxygenase expression and prostaglandin production in a mouse model of allergic airway inflammation. Immunol Lett. 2006; 106:72-81.

20. El-Mahmoudy A, Matsuyama H, Borgan MA, Shimizu Y, El-Sayed MG, Minamoto N, Takewaki T. Thymoquinone suppresses expression of inducible nitric oxide synthase in rat macrophages. Int Immunopharmacol. 2002; 2:1603-1611.

21. El-Dakhakhny M, Madi NJ, Lembert N, Ammon HP. Nigella sativa oil, nigellone and derived thymoquinone inhibit synthesis of 5-lipoxygenase products in polymorphonuclear leukocytes from rats. J Ethnopharmacol. 2002; 81:161-164.

22. El-Mahmoudy A, Shimizu Y, Shiina T, Matsuyama H, Nikami H, Takewaki T. Macrophage-derived cytokine and nitric oxide profiles in type I and type II diabetes mellitus: effect of thymoquinone. Acta Diabetol. 2005; 42:23-30.

23. Sethi G, Ahn KS, Aggarwal BB. Targeting nuclear factorkappa B activation pathway by thymoquinone: role in suppression of antiapoptotic gene products and enhancement of apoptosis. Mol Cancer Res. 2008; 6:1059-1070. 
24. Liu S, Liu Z, Xie Z, Pang J, Yu J, Lehmann E, Huynh L, Vukosavljevic T, Takeki M, Klisovic RB, Baiocchi RA, Blum W, Porcu P, et al. Bortezomib induces DNA hypomethylation and silenced gene transcription by interfering with Sp1/NF-kappaB-dependent DNA methyltransferase activity in acute myeloid leukemia. Blood. 2008; 111:2364-2373.

25. Liu Z, Xie Z, Jones W, Pavlovicz RE, Liu S, Yu J, Li PK, Lin J, Fuchs JR, Marcucci G, Li C, Chan KK. Curcumin is a potent DNA hypomethylation agent. Bioorganic \& medicinal chemistry letters. 2009; 19:706-709.

26. Shankar S, Kumar D, Srivastava RK. Epigenetic modifications by dietary phytochemicals: implications for personalized nutrition. Pharmacol Ther. 2013; 138:1-17.

27. Liu S, Wu LC, Pang J, Santhanam R, Schwind S, Wu YZ, Hickey CJ, Yu J, Becker H, Maharry K, Radmacher MD, Li C, Whitman SP, et al. Sp1/NFkappaB/HDAC/miR-29b regulatory network in KIT-driven myeloid leukemia. Cancer cell. 2010; 17:333-347.

28. Garzon R, Liu S, Fabbri M, Liu Z, Heaphy CE, Callegari E, Schwind S, Pang J, Yu J, Muthusamy N, Havelange V, Volinia S, Blum W, et al. MicroRNA -29b induces global DNA hypomethylation and tumor suppressor gene reexpression in acute myeloid leukemia by targeting directly DNMT3A and 3B and indirectly DNMT1. Blood. 2009.

29. Yang X, Pang J, Shen N, Yan F, Wu LC, Al-Kali A, Litzow MR, Peng Y, Lee RJ, Liu S. Liposomal bortezomib is active against chronic myeloid leukemia by disrupting the Sp1-BCR/ABL axis. Oncotarget. 2016; 7:36382-36394. doi: 10.18632/oncotarget.8871.

30. Mishra A, Liu S, Sams GH, Curphey DP, Santhanam R, Rush LJ, Schaefer D, Falkenberg LG, Sullivan L, Jaroncyk L, Yang X, Fisk H, Wu LC, et al. Aberrant overexpression of IL-15 initiates large granular lymphocyte leukemia through chromosomal instability and DNA hypermethylation. Cancer cell. 2012; 22:645-655.

31. Tarighat SS, Santhanam R, Frankhouser D, Radomska HS, Lai H, Anghelina M, Wang H, Huang X, Alinari L, Walker A, Caligiuri MA, Croce CM, Li L, et al. The dual epigenetic role of PRMT5 in acute myeloid leukemia: gene activation and repression via histone arginine methylation. Leukemia. 2016; 30:789-799.

32. Gholamnezhad Z, Havakhah S, Boskabady MH. Preclinical and clinical effects of Nigella sativa and its constituent, thymoquinone: A review. J Ethnopharmacol. 2016; 190:372-386.

33. Darakhshan S, Bidmeshki Pour A, Hosseinzadeh Colagar A, Sisakhtnezhad S. Thymoquinone and its therapeutic potentials. Pharmacological research. 2015; 95-96:138-158.

34. Schoofs T, Berdel WE, Muller-Tidow C. Origins of aberrant DNA methylation in acute myeloid leukemia. Leukemia. 2014; 28:1-14.

35. Figueroa ME, Lugthart S, Li Y, Erpelinck-Verschueren C, Deng X, Christos PJ, Schifano E, Booth J, van Putten W, Skrabanek L, Campagne F, Mazumdar M, Greally JM, et al.
DNA methylation signatures identify biologically distinct subtypes in acute myeloid leukemia. Cancer cell. 2010; 17:13-27.

36. van Otterdijk SD, Norden J, Dickinson AM, Pearce MS, Relton CL, Mathers JC, Strathdee G. Aberrations in DNA methylation are detectable during remission of acute lymphoblastic leukemia and predict patient outcome. Epigenomics. 2015; 7:35-45.

37. Momparler RL, Cote S, Momparler LF, Idaghdour Y. Epigenetic therapy of acute myeloid leukemia using 5-aza-2'-deoxycytidine (decitabine) in combination with inhibitors of histone methylation and deacetylation. Clin Epigenetics. 2014; 6:19.

38. Wang D, Qiao J, Zhao X, Chen T, Guan D. Thymoquinone Inhibits IL-1beta-Induced Inflammation in Human Osteoarthritis Chondrocytes by Suppressing NF-kappaB and MAPKs Signaling Pathway. Inflammation. 2015; 38:2235-2241.

39. Thummuri D, Jeengar MK, Shrivastava S, Nemani H, Ramavat RN, Chaudhari P, Naidu VG. Thymoquinone prevents RANKL-induced osteoclastogenesis activation and osteolysis in an in vivo model of inflammation by suppressing NF-KB and MAPK Signalling. Pharmacol Res. 2015; 99:63-73.

40. Xu D, Ma Y, Zhao B, Li S, Zhang Y, Pan S, Wu Y, Wang J, Wang D, Pan H, Liu L, Jiang H. Thymoquinone induces G2/M arrest, inactivates PI3K/Akt and nuclear factorkappaB pathways in human cholangiocarcinomas both in vitro and in vivo. Oncol Rep. 2014; 31:2063-2070.

41. Siveen KS, Mustafa N, Li F, Kannaiyan R, Ahn KS, Kumar AP, Chng WJ, Sethi G. Thymoquinone overcomes chemoresistance and enhances the anticancer effects of bortezomib through abrogation of NF-kappaB regulated gene products in multiple myeloma xenograft mouse model. Oncotarget. 2014; 5:634-648.doi: 10.18632/ oncotarget.1596.

42. Yu J, Peng Y, Wu LC, Xie Z, Deng Y, Hughes T, He S, Mo X, Chiu M, Wang QE, He X, Liu S, Grever MR, et al. Curcumin down-regulates DNA methyltransferase 1 and plays an anti-leukemic role in acute myeloid leukemia. PloS one. 2013; 8:e55934.

43. Park IK, Mundy-Bosse B, Whitman SP, Zhang X, Warner SL, Bearss DJ, Blum W, Marcucci G, Caligiuri MA. Receptor tyrosine kinase Axl is required for resistance of leukemic cells to FLT3-targeted therapy in acute myeloid leukemia. Leukemia. 2015; 29:2382-2389.

44. Kundu J, Choi BY, Jeong CH, Kundu JK, Chun KS. Thymoquinone induces apoptosis in human colon cancer HCT116 cells through inactivation of STAT3 by blocking JAK2- and Srcmediated phosphorylation of EGF receptor tyrosine kinase. Oncol Rep. 2014; 32:821-828.

45. Sali A, Blundell TL. Comparative protein modelling by satisfaction of spatial restraints. J Mol Biol. 1993; 234:779-815.

46. D'Aloiso L, Carlomagno F, Bisceglia M, Anaganti S, Ferretti E, Verrienti A, Arturi F, Scarpelli D, Russo D, 
Santoro M, Filetti S. Clinical case seminar: in vivo and in vitro characterization of a novel germline RET mutation associated with low-penetrant nonaggressive familial medullary thyroid carcinoma. J Clin Endocrinol Metab. 2006; 91:754-759.

47. Huey R, Morris GM, Olson AJ, Goodsell DS. A semiempirical free energy force field with charge-based desolvation. J Comput Chem. 2007; 28:1145-1152.
48. Yan F, Shen N, Pang J, Xie D, Deng B, Molina JR, Yang P, Liu S. Restoration of miR-101 suppresses lung tumorigenesis through inhibition of DNMT3a-dependent DNA methylation. Cell Death Dis. 2014; 5:e1413.

49. Hong JW, Allen CE, Wu LC. Inhibition of NF-kappaB by ZAS3, a zinc-finger protein that also binds to the kappaB motif. Proc Natl Acad Sci USA. 2003; 100:12301-12306. 